\title{
Erratum to: Perioperative fellowship curricula in anesthesiology: a systematic review
}

\author{
Angineh Gharapetian, MD • Frances Chung, MD • \\ David Wong, MD · Jean Wong, MD
}

Published online: 14 February 2015

(C) Canadian Anesthesiologists' Society 2015

\section{Erratum to: Can J Anesth/J Can Anesth \\ DOI 10.1007/s12630-014-0299-2}

In the article entitled: "Perioperative fellowship curricula in anesthesiology: a systematic review" published Online First and in the print version of the April 2015 issue of the
Journal, Can J Anesth 2015; DOI 10.1007/s12630-0140299-2, the following note should have been included on the title page: This article is accompanied by an editorial. Please see Can J Anesth 2015; 62: this issue. The publisher apologizes most sincerely for this error.

The online version of the original article can be found under doi:10. 1007/s12630-014-0299-2.

A. Gharapetian, MD (凶) · F. Chung, MD · D. Wong, MD .

J. Wong, MD

Department of Anesthesia, Toronto Western Hospital, University

Health Network, University of Toronto, Toronto, ON M5T 2S8,

Canada

e-mail: gharapetian@gmail.com 